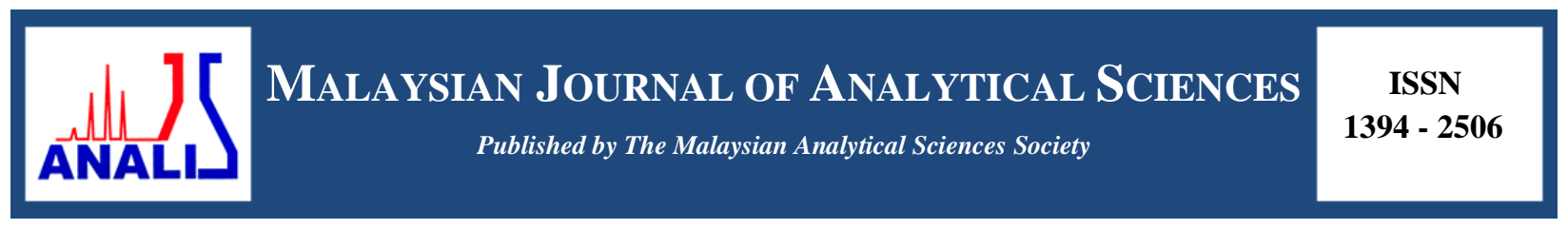

\title{
SENSORY CHARACTERISTICS OF MUD CLAM (Polymesoda erosa) HYDROLYSATE
}

\author{
(Ciri-ciri Deria Hidrolisat Lokan (Polymesoda erosa)) \\ Normah Ismail* and Noorasma Mustakim \\ Department of Food Technology, \\ Faculty of Applied Sciences, \\ Universiti Teknologi MARA, 40450 Shah Alam, Selangor, Malaysia \\ *Corresponding author: norismel@salam.uitm.edu.my
}

Received: 24 February 2015; Accepted: 27 October 2015

\begin{abstract}
Mud clam (Polymesoda erosa) was hydrolysed using two different microbial enzymes; alcalase and flavourzyme. The volatile compounds, amino acids and molecular weight associated with umami and bitter taste in mud clam hydrolysate were determined by head space solid phase micro-extraction gas chromatography (HS-SPME-GCMS), High performance liquid chromatography (HPLC) and sodium dodecyl sulphate polyacrylamide gel electrophoresis (SDS-PAGE). The characteristics of hydrolysates produced using alcalase and flavourzyme were compared. In total, eighteen, seven and six volatile compounds were identified in the flesh, alcalase hydrolysate and flavourzyme hydrolysate, respectively. 2-piperidinone volatile compound content which is associated with bitterness was $6.79 \%$ in alcalase hydrolysate and $3.78 \%$ in flavourzyme hydrolysate. SDS-PAGE results showed that alcalase hydrolysate contains smaller peptide $(<52 \mathrm{kDa})$ compared to flavourzyme hydrolysate $(<126 \mathrm{kDa})$. In addition, sensory analysis using quantitative descriptive analysis (QDA) showed that flavourzyme hydroysate was the least bitter but elicited more umami taste compared to alcalase hydrolysate. Further treatments are still needed to enhance umami taste and to remove bitter taste in mud clam hydrolysate.
\end{abstract}

Keywords: mud clam hydrolysate, volatile compounds, amino acids, molecular weight, sensory

\begin{abstract}
Abstrak
Lokan (Polymesoda erosa) telah dihidrolisiskan menggunakan dua microbial enzim yang berbeza; alcalase dan flavourzyme. Sebatian meruap, asid amino dan berat molekul yang dikaitkan dengan umami dan rasa pahit di dalam hidrolisat lokan ditentukan oleh ruang kepala pepejal mikro fasa kromatografi gas (HS-SPME-GCMS), cecair kromatografi berprestasi tinggi (HPLC) dan elektroforesis gel sodium dodekil sulfat poliakrimida (SDS-PAGE). Ciri - ciri hidrolisat dihasilkan menggunakan alcalase dan flavourzyme dibandingkan. Secara keseluruhan, lapan belas, tujuh dan enam sebatian meruap telah dikenal pasti dalam masing - masing pada isi lokan, hidrolisat alcalase dan hidrolisat flavourzyme. Kandungan sebatian meruap; 2 piperidinone yang dikaitkan dengan kepahitan adalah $6.79 \%$ pada hidrolisat alcalase dan $3.78 \%$ pada hidrolisat flavourzyme. Keputusan SDS-PAGE menunjukkan hidrolisat alcalase mengandungi peptida yang lebih kecil $(<52 \mathrm{kDa})$ berbanding hidrolisat flavourzyme (<126 kDa). Di samping itu, analisis deria menggunakan kuantitatif deskriptif analisis (QDA) menunjukkan bahawa hidrolisat flavourzyme adalah yang paling kurang pahit dan memberi rasa umami yang lebih berbanding hidrolisat alcalase. Penambahbaikan lanjut masih diperlukan untuk meningkatkan rasa umami dan untuk menghilangkan rasa pahit dalam hidrolisat lokan.
\end{abstract}

Kata kunci: hidrolisat lokan, sebatian meruap, asid amino, berat molekul, deria 


\section{Introduction}

Mud clam (Polymesoda erosa) is one of the edible bivalve species. Recently, the utilization of bivalve species becomes famous due to its high protein content and delicacy in coastal areas. Hydrolysate can be useful in food applications especially for flavour enhancer [1,2]. Hydrolysate refers to proteins that are broken down into peptide of various sizes [3]. Flavour is defined as sensations arising from the integration of signal produced as consequence of smell and taste [4]. According to Su et al. [1], the hydrolysate produced from hydrolytic enzymes can enhance the flavour of the protein hydrolysate because it increases the amount of amino acids and low molecular weight peptides that possess unique taste properties including sweet, sour and bitter tastes. The types of protease and protein substrate affect the functional and flavour profile of the protein hydrolysate [5]. Volatile compounds in protein hydrolysate of various species have been identified by several researchers using different techniques of sample preparation and methods of analysis [6]. In this study, volatile compound was extracted by using headspace solid phase micro-extraction (HS-SPME). This method was claimed to have no solvent interference and consumed less time for sample preparation. Amino acids have the most variation in taste and the effect of amino acids and peptides on food taste has been researched extensively [1,7].The amino acid compositions is important in protein hydrolysate because it contributes to the nutritional value besides influencing the functional properties and flavour of the hydrolysate [7, 8].There were several studies conducted on protein hydrolysate [9]. However, information on volatile compounds, amino acids, molecular weight and sensory related to the flavour of mud clam protein hydrolysate were limited.

Therefore, the aim of this study is to identify the volatile compounds, amino acid, molecular weight that contribute to the flavour of mud clam hydrolysate by using head space solid phase micro-extraction gas chromatography-mass spectrometry (HS-SPME-GC-MS), High performance liquid chromatography (HPLC) and sodium dodecyl sulphate polyacrylamide gel electrophoresis (SDS-PAGE). The sensory analysis using quantitative descriptive analysis (QDA) was conducted. The bitter and umami flavour of the hydrolysates produced by alcalase or flavourzyme were compared.

\section{Raw materials}

\section{Materials and Methods}

Mud clam (Poymesoda erosa) was bought from a supplier in Kuala Selangor and immediately placed in ice and transported to the laboratory. Upon arrival, the flesh was separated manually and then washed.

\section{Enzymes}

Alcalase is a bacterial endopeptidase produced by Bacillus licheniformis. Alcalase $2.4 \mathrm{~L}$ has a declared activity of 2.4 Anson Units (AU) g-1. Flavourzyme $500 \mathrm{~L}$ with declared activity of 500 Leucine Amino Peptidase Units per gram (LAPU/g) is a fungal protease/peptidase complex produced by submerged fermentation of a selected strain of Aspergillus oryzae. These two enzymes were obtained from Novozyme (Bagsvaerd, Denmark).

\section{Preparation of mud clam (Polymesoda erosa) hydrolysate}

Protein hydrolysate was prepared according to the method by Normah et al. [10]. An amount of $453 \mathrm{~g}$ flesh and 619 $\mathrm{g}$ distilled water was mixed and homogenized in a blender. The mixture was incubated in a circulated water bath. The $\mathrm{pH}$ of the mixture was adjusted to $\mathrm{pH} 8.5$ and maintained constant during hydrolysis using $4.0 \mathrm{~N}$ of $\mathrm{NaOH}$. Once the $\mathrm{pH}$ and temperature $\left(60{ }^{\circ} \mathrm{C}\right)$ has stabilized, alcalase at enzyme-substrate ratio of $3 \%$ was added and the hydrolysis continued for 2 hours. The mixture was continuously stirred using a stirring propeller throughout the hydrolysis period. At the end of hydrolysis, the enzymatic reaction was terminated by placing the samples in a water bath at $90{ }^{\circ} \mathrm{C}$ for $15 \mathrm{~min}$. This was followed by centrifugation at $10000 \mathrm{rpm}, 4{ }^{\circ} \mathrm{C}$ for $20 \mathrm{~min}$. Supernatant obtained was freeze-dried using the SANYO-Biomedical freeze dryer (ALPHA 1-4 (MARTIN CHRIST)). This procedure was repeated using Flavourzyme $500 \mathrm{~L}$ with condition at $55^{\circ} \mathrm{C}$ and $\mathrm{pH}$. The powdered hydrolysate was stored in $20{ }^{\circ} \mathrm{C}$ for further analysis.

\section{Headspace solid-phase micro-extraction (HS-SPME)}

One gram of hydrolysate sample was placed into a $15 \mathrm{~mL}$ headspace vial and pre-equilibrated for $15 \mathrm{~min}$ at $50{ }^{\circ} \mathrm{C}$ in thermostatic water bath with vial capped using a silicon septum. Afterward, stainless steel needle, PolydimethylSiloxane (PDMS) fibre was pushed through the vial septum. The fibre was pushed out of the housing 
and exposed to the headspace at $55{ }^{\circ} \mathrm{C}$ for 30 min extraction time. After extraction, the fibre was pulled into the housing and the SPME device was removed from the vial and inserted into the injection port of GC for thermal desorption of the analysis.

\section{Gas chromatography- mass spectrometry (GC-MS)}

GC-MS analysis was performed using Agilent GC-MS (Santa Clara, CA, USA). The sample was desorbed in the injection port at $250{ }^{\circ} \mathrm{C}$ for 2 minutes in splitless mode. HP-5MS analytical capillary column $(29 \mathrm{~m} \times 250 \mu \mathrm{m}$ x 0.25 $\mu \mathrm{m}$, Agilent) and helium gas at a constant flow rate of $0.8 \mathrm{~mL} / \mathrm{min}$ was used. The oven temperature was programmed at an initial temperature of $40{ }^{\circ} \mathrm{C}$ for $2 \mathrm{~min}$ followed by an increase of $5{ }^{\circ} \mathrm{C} / \mathrm{min}$ to $150{ }^{\circ} \mathrm{C}$ (held for 5 min) and finally at $10{ }^{\circ} \mathrm{C} / \mathrm{min}$ to $220{ }^{\circ} \mathrm{C}$ (held for $10 \mathrm{~min}$ ). MS operating conditions (electron impact ionization mode) were an ion source temperature of $200{ }^{\circ} \mathrm{C}$, ionization voltage of $70 \mathrm{eV}$ and mass scan range of $\mathrm{m} / \mathrm{z} 33-450$ at $2.76 \mathrm{scans} / \mathrm{s}$.

\section{Volatile compound identification}

The chromatography peak identification was carried out by comparing their mass spectra with those of the bibliographic data of known compounds from the Wiley 6 library (Hewlett-Packed Co., Palo Alto, CA) and NIST 98 library (Hewlett-Packed Co., Palo Alto, CA) mass spectral database on the basis of the criterion similarity (SI) $>800$ (the highest value is 1,000). Results are presented as the percent area (\%).

\section{Amino acid analysis}

An amount of 0.1 grams mud clam hydrolysate or flesh was hydrolysed using $6 \mathrm{~N} \mathrm{HCl}$ at $110{ }^{\circ} \mathrm{C}$ for 24 hours and derivatised using phenyl isothiocyanate prior to AccQ Tag HPLC analysis. The total amino acid was analysed by the AccQTag method using an AccQ Tag column $(3.9 \times 150 \mathrm{~mm})$ at a flow rate of $1 \mathrm{~mL} / \mathrm{min}$ equipped with fluorescence detector. The mobile phase used was AccQTaq Eluent A consists of $100 \mathrm{~mL}$ Eluent A and $1000 \mathrm{~mL}$ deionized water while AccQ Tag Eluent B consists of $60 \%$ acetonitrile and $40 \%$ deionized water. The total running time per injection was 50 minutes.

\section{Sodium dodecyl sulphate polyacrylamide gel electrophoresis (SDS-PAGE)}

SDS PAGE was used to determine the molecular weight of the mud clam flesh and mud clam hydrolysate. An amount of $0.1 \mathrm{~g}$ of powdered sample was dissolved in $10 \mathrm{~mL}$ deionized water and then filtered using membrane filter with pore sizes $0.45 \mu \mathrm{m}$. Filtered solution at $6.5 \mu \mathrm{L}$ was mixed with $2.5 \mu \mathrm{L}$ NuPAGE ${ }^{\circledR} \mathrm{LDS}$ sample Buffer $(4 \mathrm{X})$ and $1 \mu \mathrm{L}$ NuPAGE ${ }^{\circledR}$ Reducing Agent $(10 \mathrm{X})$. The mixture was heated at $70^{\circ} \mathrm{C}$ for 10 minutes in water bath. Ten $\mu \mathrm{L}$ sample was loaded into each well of the SDS-PAGE system comprising of $12 \%$ resolving gel and $5 \%$ stacking gel. Benchmark $^{\mathrm{TM}}$ protein ladder is used as a standard marker at the range of 175 to $9 \mathrm{kDa}$.

Electrophoresis was performed using the XCellSurelock electrophoresis cell (Bio-Rad laboratories, Hercules, CA, USA). Electrophoresis was run for 50 minutes at $100-125 \mathrm{~mA} / \mathrm{gel}$. After the running process, the gels were washed with $100 \mathrm{~mL}$ of ultrapure water. Then, the gel was stained using staining solution containing Coomassie Brilliant Blue dye and heated in a microwave oven at $180^{\circ} \mathrm{C}$ for one minute. The gel was shaken again in the orbital shaker for about 2 minutes. The process was repeated twice. The gel were destained using Ultrapure water and shaken with orbital shaker for another 30 minutes.

\section{Identification of bitter and umami taste}

Sensory evaluation for bitterness and umami taste of mud clam hydrolysate was conducted using qualitative descriptive analysis (QDA). Ten panellists were trained for three weeks by using caffeine and monosodium glutamate (MSG) solution to represent the bitter and umami taste. Different concentrations of caffeine solutions $(0.05-2.00 \%)$ and MSG solutions $(1$ to $200 \mathrm{mM})$ were prepared and presented to the panellists. The lowest concentration that the panellist could perceive was identified and this concentration was used as the reference to evaluate the degree of bitterness and umaminess of mud clam hydrolysates. A $15 \mathrm{~cm}$ scale anchored from 'none to strong bitterness' was used for the evaluation. Mud clam hydrolysate $(2.5 \%(\mathrm{w} / \mathrm{v}))$ were prepared and presented to the panellists. 


\section{Statistical analysis}

The data obtained was analysed using the Analysis of Variance (ANOVA) to determine significance at $5 \%$ level. Duncan Multiple Range Test (DMRT) was used to identify differences between means. Two sample t-tests were used to compare the mean values. Values were expressed as means \pm standard deviations. The significant difference between two means was obtained when $t$ value $<\mathrm{p}$ value 0.05 .The statistical program used was SPSS software (Version 16.0) for Windows (SPSS Inc. Chicago, IL).

\section{Volatile compound analysis}

\section{Results and Discussion}

Savoury taste in seafood product is important to give a higher degree of acceptability among customer. This taste is dependent on the composition of volatile compounds. The number of compounds detected and identified were eighteen, seven and six for mud clam flesh, alcalase hydrolysate and flavourzyme hydrolysate, respectively (Table 1). Two different types of volatile alcohol (2-furanmethanol and benzyl alcohol) were only detected in the flesh and flavourzyme hydrolysate. According to Jin et al. [11], alcohols do not affect the flavour of food unless they are present in large amount because of their high threshold values. Mud clam flesh contains higher percent of hydrocarbon compound compared to the hydrolysate. Nor Qhairul Izzreen and Vijaya Ratnam [12] stated that high percentage of hydrocarbon in seafood is very common. Esters are produced by esterification with alcohols and carboxylic acid. According to Jin et al. [11], the content of esters increased slightly in fish processed products. Esters of low molecular weight greatly affect the sweet, fruity and candy-like flavour of salted and fermented anchovies [13]. Nitrogen- containing compound such as pyrazines were reported to have nutty, roasted or toasted aroma in most foods $[8,14] .2,5$ dimethylpyrazine compound was higher $(4.09 \%)$ in flavourzyme hydrolysate compared to those in alcalase hydrolysate $(1.01 \%)$. These compounds were the predominant aroma active compound in cooked shrimp, crab and seaweed $[6,15,2]$. Fatty acid are considered important compound in seafood flavour [2]. Fatty acid such as 2-propenoic acid, tetradecanoic acid and hexadecanoic acid was only identified in mud clam flesh as shown in Table 1.

Table 1. Major volatile compounds in mud clam flesh, alcalase hydrolysate and flavourzyme hydrolysate

\begin{tabular}{lccc}
\hline Volatile compounds & \multicolumn{2}{c}{ Percent area (\%) } \\
\cline { 2 - 4 } & $\begin{array}{c}\text { Mud clam } \\
\text { flesh }\end{array}$ & $\begin{array}{c}\text { Alcalase } \\
\text { hydrolysate }\end{array}$ & $\begin{array}{c}\text { Flavourzyme } \\
\text { hydrolysate }\end{array}$ \\
\hline 2-Furanmethanol & 1.84 & n.d. & n.d. \\
Benzyl Alcohol & n.d. & n.d. & 15.10 \\
Hexadecanoic acid, methyl ester & 1.80 & 48.96 & n.d. \\
Octadecanoic methyl ester & n.d. & 16.61 & n.d. \\
1,2-Benzenedicarbocylicacid, & 0.99 & n.d. & 26.62 \\
diisooctyl ester & & & n.d. \\
2-Propenoic acid & 0.74 & n.d. & n.d. \\
Tetradecanoic acid & 20.51 & n.d. & n.d. \\
n-hexadecanoic acid & 33.28 & n.d. & 6.68 \\
4H-Pyran-4-one, 2,3-dihydro-3, & 4.52 & n.d. & \\
5-dihyroxy-6-methyl & & & 3.87 \\
Cyclopentasiloxane, decamethyl & 1.83 & 2.17 & n.d. \\
Heptadecane & 0.97 & 0.27 & n.d. \\
Octadecane & 1.48 & 0.13 & n.d. \\
Cyclopentadecane & 1.57 & n.d. & \\
\hline
\end{tabular}

n.d. $=$ not detectable 
Table 1 (cont'd). Major volatile compounds in mud clam flesh, alcalase hydrolysate and flavourzyme hydrolysate

\begin{tabular}{lccc}
\hline \multirow{2}{*}{ Volatile compounds } & \multicolumn{2}{c}{ Percent area (\%) } \\
\cline { 2 - 4 } & $\begin{array}{c}\text { Mud clam } \\
\text { flesh }\end{array}$ & $\begin{array}{c}\text { Alcalase } \\
\text { hydrolysate }\end{array}$ & $\begin{array}{c}\text { Flavourzyme } \\
\text { hydrolysate }\end{array}$ \\
\hline Nonadecane & 2.18 & n.d. & n.d. \\
Eicosane & 2.63 & n.d. & n.d. \\
Docasane & 2.51 & n.d. & n.d. \\
Heneicosane & 3.73 & n.d. & n.d. \\
Cholesta-3,5-diene & 4.33 & n.d. & n.d. \\
Tetracosane & 2.87 & n.d. & n.d. \\
Hexacosane & 2.15 & n.d. & n.d. \\
2,5 dimethylpyrazine & n.d. & 1.01 & 4.09 \\
2-Piperidinone & n.d. & 6.79 & 3.78 \\
\hline
\end{tabular}

n.d. $=$ not detectable

According to Natta et al. [2], fatty acids were not found due to thermal degradation of lipids. 2-piperidinone is from amide group which caused bitter flavour was presence in both hydrolysates. The flavourzyme hydrolysate gave significantly lower content of 2-piperidinone (3.78 \%) compared to alcalase hydrolysate (6.79\%). This finding was in agreement with amino acid and sensory analysis which indicated that alcalase hydrolysate has significantly higher degree of bitterness compared to flavourzyme hydrolysate. These compounds were also found in fermented castor oil bean [16].

\section{Amino acids content}

The amino acids content in mud clam flesh and hydrolysates is shown in Table 2. The total amino acids were 75.23 $\%, 62.37 \%$ and $47.66 \%$ for alcalase hydrolysate, flavourzyme hydrolysate and mud clam flesh, respectively. The amino acids grouping based on their taste characteristic as described by Tseng et al. [17] are shown in Table 2. The bitter amino acid was predominant taste in those three samples. Alcalase hydrolysate contains highest amount of bitter like amino acids (46.76 \%) followed by flavourzyme hydrolysate (37.79\%) and mud clam flesh (30.4\%). The MSG-like amino acids (aspartic acid and glutamic acid) were $5.06 \%$ in alcalase hydrolysate followed by mud clam flesh with $3.45 \%$ and flavourzyme hydrolysate which is $3.28 \%$. This result was in agreement with sensory data in which alcalase hydrolysate gave higher bitter taste compared to flavourzyme hydrolysate. According to Zhang and Tao [7] who studied on the final taste characteristic of five different types of soy sauce revealed that the balance and interaction between different taste components in amino acid gave different taste to every sauce.

\section{Sodium dodecyl sulphate polyacrylamide gel electrophoresis (SDS-PAGE)}

The molecular weight distributions of mud clam flesh and mud clam hydrolysates are shown in Figure 1. More intense bands with wide molecular weight range were observed in mud clam flesh compared to both hydrolysates. This showed that both enzymes are capable of breaking the protein into the smaller peptides. Mud clam hydrolysate produced from alcalase has lower molecular weight $(<52 \mathrm{kDa}$ ) compared to flavourzyme hydrolysate $(<126 \mathrm{kDa})$. Therefore, alcalase hydrolysate was bitterer than flavourzyme hydrolysate which is in line with sensory analysis. 
Table 2. Total amino acids content $\left(\mathrm{g}_{100 \mathrm{~g}^{-1}}\right)$ in mud clam flesh, alcalase and flavourzyme hydrolysate based on their taste characteristic

\begin{tabular}{lccc}
\hline Amino acid & $\begin{array}{c}\text { Mud clam } \\
\text { flesh }\end{array}$ & $\begin{array}{c}\text { Alcalase } \\
\text { hydrolysate }\end{array}$ & $\begin{array}{c}\text { Flavourzyme } \\
\text { hydrolysate }\end{array}$ \\
\hline MSG-like* & $0.15 \pm 0.01$ & $0.96 \pm 0.02$ & $0.42 \pm 0.01$ \\
Asp & $3.30 \pm 0.40$ & $4.10 \pm 0.38$ & $2.86 \pm 0.91$ \\
Glu & 3.45 & 5.06 & 3.28 \\
Total & & & \\
\hline Sweet* & $2.21 \pm 0.93$ & $1.86 \pm 0.53$ & $1.43 \pm 0.31$ \\
Ala & $2.64 \pm 0.94$ & $1.71 \pm 0.51$ & $2.09 \pm 0.21$ \\
Gly & $1.38 \pm 0.29$ & $3.57 \pm 0.14$ & $5.14 \pm 0.10$ \\
Ser & $1.21 \pm 0.20$ & $2.79 \pm 0.47$ & $1.41 \pm 0.33$ \\
Thr & 7.44 & 9.93 & 10.07 \\
Total & & & \\
\hline Bitter* & $2.84 \pm 0.52$ & $5.29 \pm 0.83$ & $2.09 \pm 0.21$ \\
Arg & $4.10 \pm 0.96$ & $5.69 \pm 0.91$ & $3.81 \pm 0.88$ \\
His & $1.60 \pm 0.50$ & $2.45 \pm 0.56$ & $1.01 \pm 0.67$ \\
Ile & $1.61 \pm 0.52$ & $4.89 \pm 0.42$ & $5.98 \pm 0.86$ \\
Leu & $1.72 \pm 0.41$ & $3.71 \pm 0.32$ & $0.68 \pm 0.59$ \\
Met & $17.18 \pm 0.11$ & $21.56 \pm 0.41$ & $23.12 \pm 0.40$ \\
Phe & $1.35 \pm 0.10$ & $3.17 \pm 0.59$ & $1.10 \pm 0.02$ \\
Val & 30.4 & 46.76 & 37.79 \\
Total & & & \\
\hline Tasteless* & $0.47 \pm 0.56$ & $6.54 \pm 0.70$ & $7.38 \pm 0.88$ \\
Cys & $2.02 \pm 0.91$ & $2.97 \pm 0.86$ & $1.58 \pm 0.92$ \\
Lys & $3.62 \pm 0.39$ & $2.72 \pm 0.23$ & $1.14 \pm 0.06$ \\
Pro & 6.11 & 12.23 & 10.1 \\
Total & & & \\
\hline Valyes & & & \\
\hline
\end{tabular}

Values are expressed as means \pm standard deviation from triplicate determinations, *Amino acids grouping based on taste as described by [17].

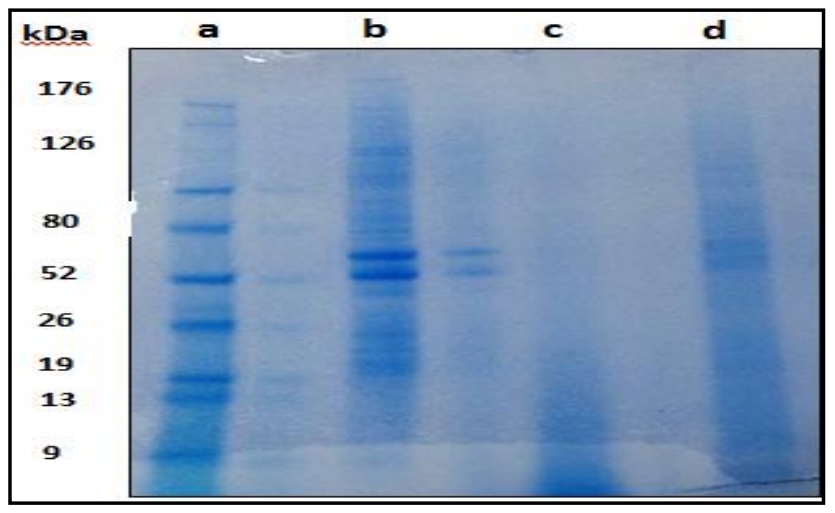

Figure 1. Molecular weight distributions of (a) protein marker, (b) mud clam flesh, (c) alcalase hydrolysate and (d) flavourzyme hydrolysate. 
Identification of degree of bitterness and umami taste

The bitterness and umami taste of mud clam hydrolysate were evaluated using caffeine and monosodium glutamate (MSG) solutions. The score for bitterness using 15-cm line scale with anchor from 'none' to 'very strong' for alcalase hydrolysate was $6.60,3.56$ for flavourzyme hydrolysate and 9.66 for caffeine solution.
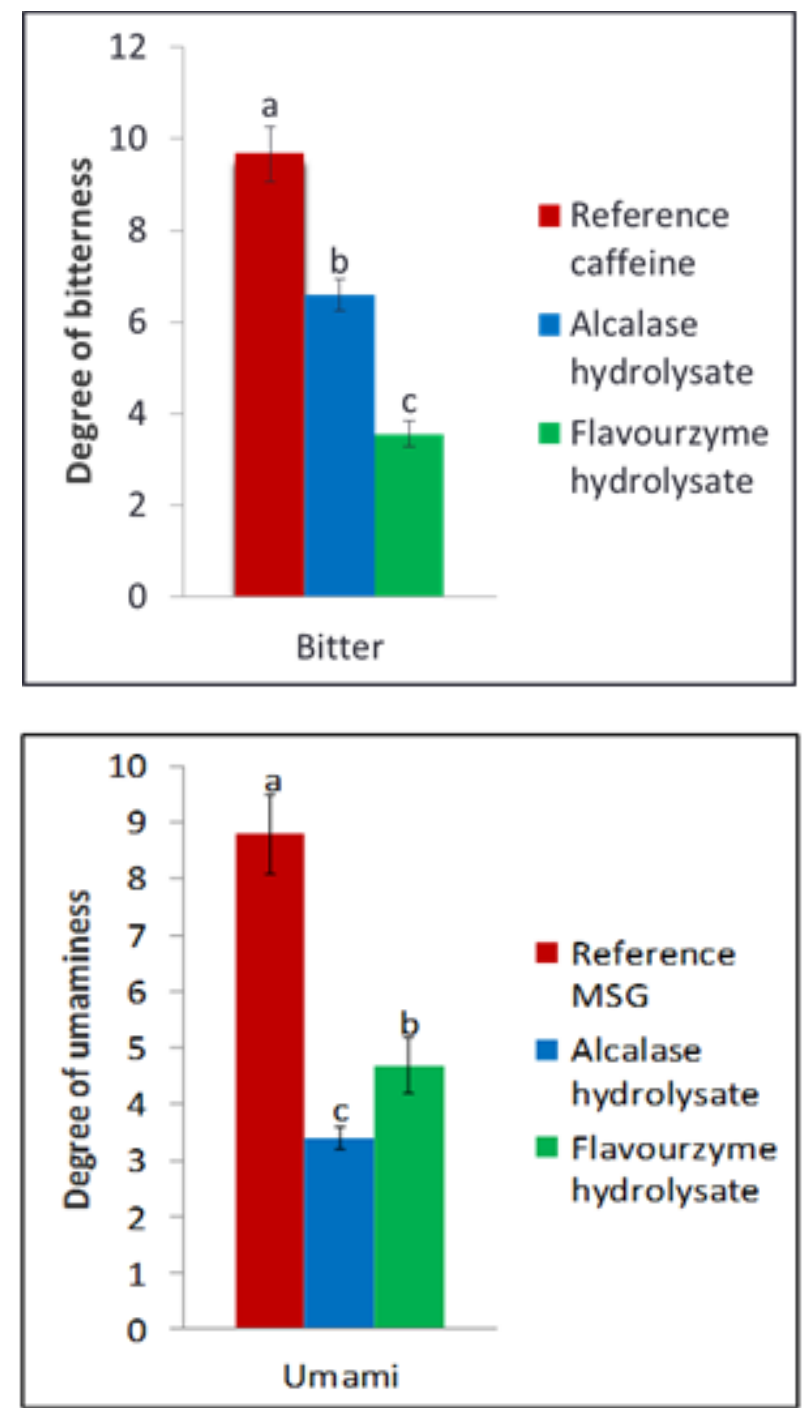

Figure 2. Degree of bitterness and umaminess of mud clam hydrolysates. Values are expressed as means \pm standard deviation. Different letters indicate significant different at $\mathrm{p}<0.05$

This result revealed that the bitterness of the hydrolysates and caffeine solution were in the following order: flavourzyme hydrolysate <alcalase hydrolysate < caffeine reference solution. This result was in agreement with total amino acids content in which alcalase hydroysate had higher amount of bitter taste amino acids compared to flavourzyme hydrolysate. For umami taste, the reference monosodium glutamate (MSG) degree of umaminess was significantly higher $(\mathrm{p}<0.05)$ compared to alcalase and flavourzyme hydrolysate (Figure 2). Flavourzyme 
hydrolysate was perceived to be slightly more umami than alcalase hydrolysate by the panellists which could be associated with higher content of the sweet amino acids.

\section{Conclusion}

Volatile compound (2-piperidinone) that contributes to bitter taste was identified in hydrolysate. Alcalase hydrolysate has higher bitter like amino acid content compared to those of flavourzyme. The sensory analysis also suggested that flavourzyme hydrolysate was less bitter than alcalase hydrolysate. Both hydrolysates showed lower umami value than the reference umami solution. Further treatment of mud clam protein hydrolysate is needed to reduce the bitter taste and to enhance the umami taste in order to give more acceptable product.

\section{Acknowledgement}

The authors would like to thank for all the laboratory staff of Food Technology Department and facilities provided from the Faculty of Applied Sciences, Universiti Teknologi MARA (UiTM), Shah Alam campus.

\section{References}

1. Su, G., Cui, C., Zheng, L., Yang, B., Ren, J. and Zhao, M. (2012). Isolation and identification of two novel umami and umami-enhancing peptides from peanut hydrolysate by consecutive chromatography and MALDITOF/TOF MS. Food Chemistry, 135: $479-485$.

2. Natta, L., Orrapun, S. and Orapin, K. (2014). Seafood-like flavour obtained from the enzymatic hydrolysis of the protein by-products of seaweed (Gracilaria sp.). Food Chemistry, 158: $162-170$.

3. Adler-Nissen, J. (1986). Enzymic hydrolysis of food proteins. New York: Elsevier Applied Science Publishers.

4. Laing, D. G. and Jinks, A. (1996). Flavour perception mechanisms. Trends in Food Science and Technology, 7: $387-389$.

5. McCarthy, A., O'Callaghan, Y. and O'Brien, N. (2012). Protein hydrolysates from agricultural crops bioactivity and potential for functional food development. Agriculture, 3(1): $112-130$.

6. Morita, K., Kubota, K. and Aishima, T. (2001). Sensory characteristics and volatile components in aromas of boiled prawns prepared according to experimental designs. Food Research International, 34: 473 - 481.

7. Zhang, Y. and Tao, W. (2009). Flavour and taste compounds analysis in Chinese solid fermented soy sauces. African Journal of Biotechnology, 8(4): 673 - 681.

8. Oh, K. S, Kang, S. T and Ho, C. T. (2001). Flavour constituents in enzyme hydrolysates from shore swimming crab and spotted shrimp. Journal Korean Society of Food Science and Nutrition, 30: 787 - 795.

9. Sathivel, S., Bechtel, P. J., Babbitt, J., Smiley, S., Crapo, C. and Reppond, K. D. (2003). Biochemical and functional properties of herring (Clupea harengus) byproduct hydrolysates. Food Chemistry and Toxicology, 68: $2196-2200$.

10. Normah, I., Siti Hafsah, M. S. and Nurul Izzaira, A. (2013).Bitterness of green mussel (Perna viridis) hydrolysate as influenced by the degree of hydrolysis. International Food Research Journal, 20(5): 2261 2268.

11. Jin, Y. P., Ye, J. K. and Yang, B. L. (2014). Analysis of headspace volatile compounds in cold-stored and freeze-dried krill Eupausia superb. Fish Aquatic Science, 17(2): 189 - 195.

12. Nor Qhairul Izzreen, M. N. and Vijaya Ratnam, R. (2011).Volatile compound extraction using solid phase micro extraction coupled with gas chromatography mass spectrometry (SPME-GCMS) in local seaweeds of Kappaphycus alvarezii, Caulerpa lentillifera and Sargassum polycystem. International Food Research Journal, 18(4): $1449-1456$.

13. Cha, Y. J., Cho, W. J and Jeong, E. J. (2006). Comparison of volatile flavour compounds in commercial crablike flavorants by analyzing methods. Journal of Life Sciences, 16: $1243-1249$.

14. Ahn, J. S., Cho, W. J., Jeong, E. J. and Cha, Y. J. (2006). Reaction technology for making natural crab like flavoran from snow crab processing by-products. Journal Korean Fish Society, 39: 437 - 440.

15. Yu, H. Z. and Chen, S. S. (2010). Identification of characteristic aroma-active compounds in steamed mangrove crab (Scylla serrata). Food Research International, 43: 2081 - 2086.

16. Ojinnaka, M. C. and Ojimelukwe, P. C. (2013). Study of the volatile compounds and amino acid profile in Bacillus fermented castor oil bean condiment. Journal of Food Research, 2: $191-203$.

17. Tseng, Y. H., Lee, Y. L., Li, R. C. and Mau, J. L. (2005). Non-volatile flavour components of Ganoderma tsugae. Food Chemistry, 90: 409 - 415. 